\title{
Pengaruh Faktor Air Semen (FAS) Terhadap Toughness Beton
}

\section{Influence Of Water Cement Factor (WCF) On Toughness Concrete}

\author{
Armin Naibaho
}

Jurusan Teknik Sipil Politeknik Negeri Malang Email: ar_naibaho@yahoo.co.id

\begin{abstract}
The pupose of this research is to observe the effect of water cement factors to the toughness of concrete :"How is the effect of water cement factors to the toughness of concrete?" Laboratory testing is done for concrete base material, that is aggregate: Rough (pebble), fine aggregate (sand), cement ( $\mathrm{PC}=$ Portland Cement), water. The test object is in the form of a cylinder with mix design that have variation at water cement factors (cement water factors 0,35 , cement water factors 0,40 , and cement water factors 0,45 ) for 10 pieces, which is soaked for 26 days. On the $28^{\text {th }}$ day, the object will be tested press.

Based on analysis and discussion, then obtained that (1) From the mixed composistion based on Water Cement Factors, it is seen that the mixture using the lowest water cement factors, Cement Water Factors 0.35 will give a stronger press value and larger elastic modulus, 23,36 MPa at Cement Water Factors $0.40(11,34 \%)$ and increased to 26,68 Mpa at Cement Water Factors 0.35 (27,17\%). (2) Compared to the lowest Cement Water Factors, Cement Water Factors 0.35 will give a higher Work of Fracture $\left(\mathrm{G}_{\mathrm{f}}\right)$. This is shown from Work of Fracture $\left(\mathrm{G}_{\mathrm{f}}\right)$ to Cement Water Factors $0.45=31,445 \mathrm{~N} / \mathrm{m}$, increased to $34,582 \mathrm{~N} / \mathrm{m}$ at Cement Water Factors $0.40(9,025 \%)$ and increased to $35,582 \mathrm{~N} / \mathrm{m}$ at Cement Water Factors $0.35(13,156 \%)$. (3). Quantitatively the hardness, the bigger value of power achieved will show the bigger concrete ductile. This is shown from Stress Intensity Factor $(\mathrm{K})$ to Cement Water Factors $0.45=0,8267 \mathrm{~N} / \mathrm{m}$, incresed to $0,8664 \mathrm{~N} / \mathrm{m}$ at Cement Water Factors $0.40(4,80 \%)$ and increased to $0,9088 \mathrm{~N} / \mathrm{m}$ at Cement Water Factors 0.35 (9,93\%).
\end{abstract}

Keywords: normal concrete, toughness, compressive strength, mixed variations, and cement water Factors.

\section{PENDAHULUAN}

Beton merupakan bahan konstruksi yang banyak digunakan disamping kayu dan baja. Opini masyarakat untuk menggunakan material beton sebagai bahan konstruksi bangunan semakin mantap dibandingkan dengan bahan material lainnya.

Bahan dasar pembentuk beton terdiri dari : semen, agregat, air dan bahan tambahan, dengan volume agregat kurang lebih $70 \%$ dari volume betonnya. Sehingga agregat beton juga merupakan bahan utama yang juga menentukan sifat-sifat beton yang akan dibuat. Agregat yang dimaksud menyangkut agregat halus (pasir) dan agregat kasar ( kerikil).

Menurut Paulus Nugraha (1989), kekuatan beton tergantung: kekuatan agregat (khususnya agregat kasar), kekuatan pasta semen, kekuatan ikatan semen dengan agregat. Beton yang baik bila kekuatan agregat lebih besar dari pada yang lain, sehingga kekuatan beton tergantung pada kekuatan dari semen yang terhidrasi dan ikatannya.

Lawrence H.Van Vlack (2001), mendifinisikan toughness adalah ukuran dari energy yang diserap sebelum terjadi perpatahan/kehancuran. Jadi besarnya kemampuan untuk mendisifasi/menyerap energy dari beton tersebut sebelum terjadi hancur merupakan toughness beton tersebut. Tentunya toughness beton ini akan dipengaruhi oleh agregat betonnya. Untuk penelitian ini difokuskan pada sejauh mana redistribusi yang diberikan oleh faktor air semen (fas) dengan variasi fas terhadap toughness beton. Sedangkan diameter maksimum dan bentuk permukaan/tekstur dari agregat kasar untuk semua variasi disamakan.

Beton merupakan material komposit : kekuatannya adalah fungsi dari kekuatan semen, kekuatan agregat dan interaksi 
antara komponen - komponennya (Paulus Nugraha,1989). Beton adalah suatu material yang terbentuk dari campuran pasta semen (adukan semen dan air) dengan agregat (pasir dan kerikil), yang bisa ditambahkan suatu bahan tambahan (additive,admixture) tertentu sesuai kebutuhan untuk mencapai kinerja (performance) yang diinginkan (Supartono F.X., 2001).

Agregat adalah butiran material antara lain pasir, kerikil, batu pecah atau bubuk besi hasil dari sisa pengikiran dari pemolesan, diikat dengan semen menjadi spesi beton (Tata Surdia dan Shinroku Saito , 1984). Dalam pengetahuan bahan agregat ini dibagi kedalam agregat kasar dan agregat halus. Lebih lanjut dijelaskan; Agregat yang baik seharusnya mempunyai sifat-sifat sebagai berikut (Tata Surdia dan Shinroku Saito , 1984) : 1).Keras dan kuat; 2).Bersih; 3).Tahan lama; 4).Massa jenis tinggi; 5).Butir bulat; 6).Distribusi ukuran butir yang variatif dan cocok. Berikut ini tipikal regangan-tegangan dari beton dan material unsur material pembentuknya.

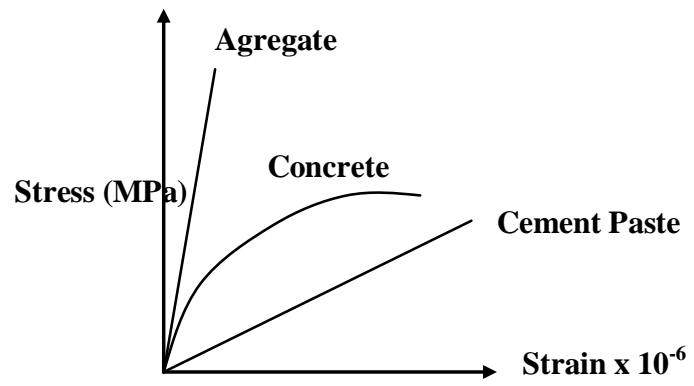

Gbr 1. Tipikal Reg-Teg. beton dan unsur material.

Reaksi antara semen dan air, dibedakan menjadi dua periode yang berlainan, yaitu : 1).Periode pengikatan yaitu peralihan dari keadaan plastis ke dalam keadaan keras menyangkut; periode pengikatan awal ( dari awal pengecoran sampai \pm 1 jam) dan periode pengikatan akhir ( dari \pm 1 jam sampai \pm 3 jam). 2).Periode pengerasan yaitu penambahan kekuatan setelah pengikatan selesai. Yang terpenting adalah awal pengikatan, yaitu saat mulainya semen menjadi kaku, yang tidak boleh terjadi kurang dari satu jam ( Tri Mulyono , 2003).
Jumlah air total adalah seluruh air yang ada, baik yang di dalam pori maupun yang di luar butir. Kadar air total adalah prosentase jumlah air tersebut terhadap berat agregat kering. Sedangkan kadar air bebas adalah prosentase jumlah air yang di luar butir saja. Kadar air bebas ini dipakai sebagai dasar untuk perencanaan campuran, karena agregat dianggap dalam keadaan SSD.

\section{Kekuatan tekan beton.}

Kekuatan tekan beton adalah muatan tekan maksimum yang dapat dipikul oleh karena bertambahnya kekuatan tekan beton, maka sifat - sifat bertambah baik.

Kuat tekan dipengaruhi beberapa faktor utama yaitu sifat agregat (kekakuan, kekerasan dan kepadatannya), diameter maksimum agregat, gradasi, faktor air semen, dan mutu pengerjaannya ( pengadukan dan pemadatan yang sempurna akan menghasilkan material beton dengan kadar pori minimum).

\section{Faktor air semen (FAS)}

Pada campuran beton, air memiliki fungsi, yaitu sebagai material yang memungkinkan reaksi hidrasi terjadi sehingga semen akan mengalami pengikatan dan pengerasan.

Dalam fungsinya sebagai pemicu reaksi hidrasi pada semen tersebut, proporsi air terhadap semen menjadi sangat penting. Untuk 1 bagian berat semen membutuhkan sekitar 0,25 bagian berat air untuk hidrasi. Jika proporsi air terhadap semen sangat kecil, maka reaksi hidrasi tidak akan dapat berjalan dengan sempurna karena ada sebagian butiran semen yang tidak tersentuh oleh air. Namun apabila proporsi air terhadap semen terlalu besar, maka kelebihan air akan mengisi ruang diantara butiran pasta, dan saat seluruh air menguap ketika beton mengering akibat hidrasi, akan terbentuk rongga-rongga yang ditinggalkan oleh air.

Terdapat dua sumber utama pembentuk rongga pada beton, yaitu gelembung udara yang terperangkap dan air kelebihan yang mengisi ruang antar pasta dan akhirnya menguap saat beton mengering. 
Berdasarkan uraian di atas dapat disimpulkan bahwa "Pada bahan-bahan beton dan kondisi pengujian tertentu, jumlah air dalam campuran (factor air semen) menentukan kekuatan beton, selama campuran cukup plastis dan dapat dikerjakan". Hal ini berarti bahwa beton yang dipadatkan sempurna dengan agregat yang baik dan pada kadar semen tertentu, maka kekuatannya tergantung pada factor air semen.

Kenaikan factor air semen mempunyai pengaruh yang besar terhadap kinerja beton seperti permeabilitas, thowing and freezing, ketahanan terhadap abrasi, kekuatan tarik, kekuatan tekan, rayapan, modulus rupture, robek dan susut.

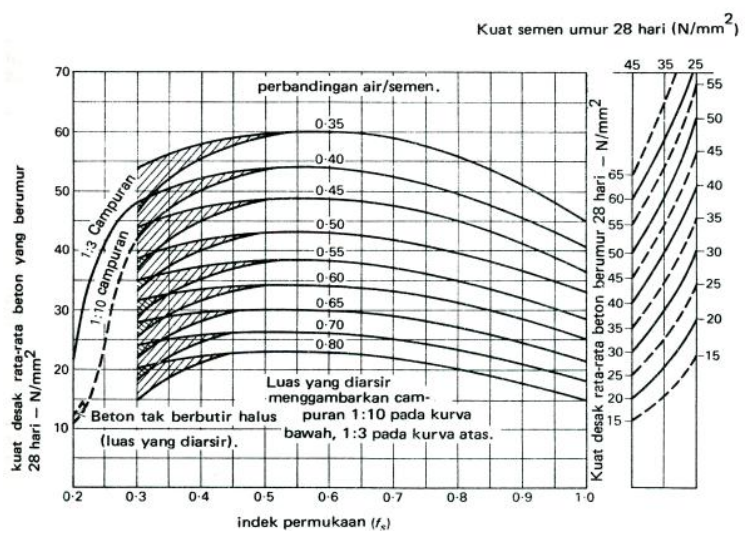

Gbr 3. Hubungan antara FAS dengan Kekuatan tekan Beton

\section{Pengertian Toughness (Ketegaran).}

Ketegaran adalah ukuran yang menunjukkan energi yang diperlukan hingga terjadi perambatan perpatahan/kehancuran (Lawrence H.Van Vlack , 2001). Luas total diagram teganganregangan disebut modulus ketegaran/ketangguhan, modulus ini menyatakan energi yang diserap per-satuan volume (Ferdinand L.Singer,dkk, 1995). Ketegaran ini sering dikenal sebagai ketangguhan (toughness). Ketegaran itu merupakan laju keruntuhan struktur yang ditentukan oleh kemampuan materialnya dalam mendisipasi energi ( Keitetsu Rokugo.cs , 1995). Sifat bahan yang berhubungan dengan kemampuannya dalam menahan retak/patah/hancur disebut dengan ketegaran (Rocman A., 2001).

\section{Konsep Toughness (Ketegaran).}

Untuk lebih memahami ketegaran, berpatokan pada buku : "Mechanics of Materials" oleh David Roylance (1996), mengambil konsep : Contoh pada busur panah (seperti ditunjukkan gambar 6).

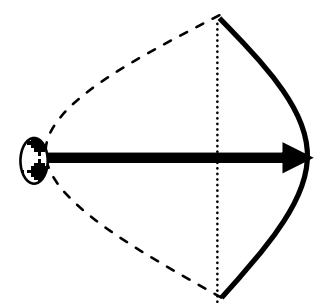

Gbr 4. Sebuah panah ditarik dari busurnya. Sumber : David Roylance ,1996

Agar bekerja dengan baik, busur tidak dapat terlalu kaku sehingga menyimpan energi tegangan yang substansial maka ditarik lebih lanjut supaya energinya akan lebih kuat. Peristiwa penyimpanan dan penyerapan energi inilah yang dimaksud dengan Ketegaran tersebut.

Sehingga bila konsep ini diterapkan pada material beton, maka besarnya kemampuan untuk menyerap/disipasi energi dari beton (material) tersebut sebelum terjadi hancur merupakan ketegaran dari beton tersebut. Yang ingin dilihat sejauh mana redistribusi yang diberikan oleh faktor air semen (fas) ini terhadap ketegaran beton dengan memperhatikan kinerja dari beton tersebut.

\section{Pengelompokan/pembagian Peristiwa Ketegaran Beton Normal.}

Sesuai dengan penjelasan pada konsep ketegaran di atas, maka peristiwa ketegaran ini dapat dikelompokkan menjadi dua bagian, yaitu :

a. Toughnees (Ketegaran) Pre Peak, yaitu ketegaran yang terjadi sebelum tercapai puncak (Pre Peak). 


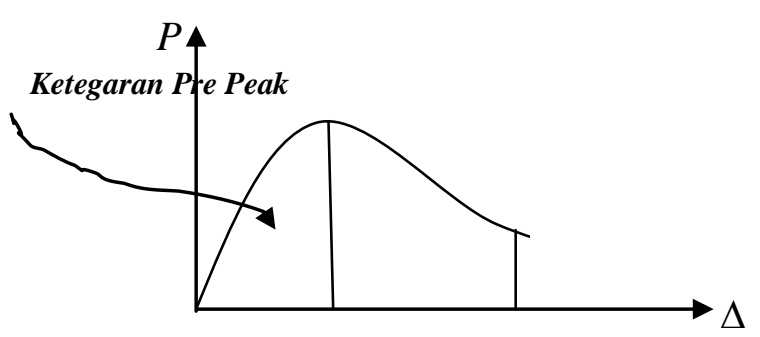

Gbr 5. Ketegaran Pre Peak.

Ketegaran yang terjadi setelah tercapai puncak (Post Peak).

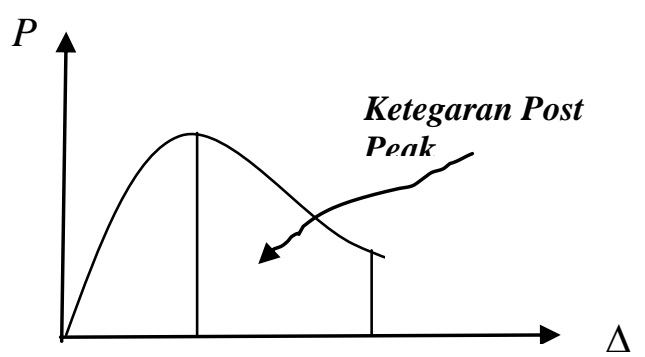

Gbr 6. Ketegaran Post Peak.

\section{Menganalisis Ketegaran Beton.}

Untuk mengetahui dan menghitung besar ketegaran pada tiap-tiap perlakuan digunakan formulasi sebagai berikut :

a. Menghitung luas bidang permukaan di bawah kurva BebanPenurunan/defeksi di atas dengan persamaan :

Hal ini merujuk pada kurva - Shah dkk, 1995 halaman 163, diperoleh nilai W :

$\mathbf{W}=\mathbf{P} \cdot \Delta l$

b. Menghitung Besar Energi Retak /Work of Fracture $=\mathbf{G}_{\mathbf{f}}$.

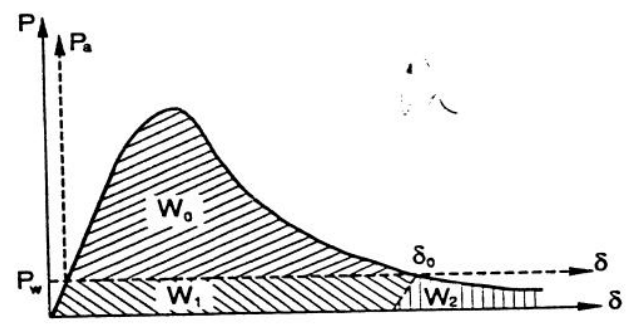

Gbr 8. Luas Kurva (W) pada

Hub.Beban(P)-Penurunan $(\Delta l)$

Sumber : Shah dkk, 1995

Untuk menghitung besar energi retak, merujuk pada persamaan 6.5 - Shah dkk, 1995 halaman 166, diperoleh:

$$
G_{f}=\frac{W}{A_{r}}
$$

c. Menghitung besar Faktor Intensitas Tegangan (toughness) $=\mathrm{K}$.

Hal ini merujuk pada persamaan 7.6 Shah dkk, 1995 halaman 248, diperoleh:

$$
K=\sqrt{E . G}_{f}
$$

dengan ;

$\mathrm{E}=$ Modulus elastisitas silinder pada tiap-tiap perlakuan (Mpa).

$\mathrm{G}_{\mathrm{f}}=$ Energi retak $(\mathrm{N} / \mathrm{m})$

\section{Beberapa Rujukan Penelitian} Sebelumnya tentang Ketegaran Beton.

a. Penelitian dari Sunardi :

Topik ; "Menentukan Nilai Keteguhan Beton Normal dan Beton Mutu Tinggi pada Permukaan dalam Akibat Penurunan Faktor Kohesif ". Kesimpulan : Semakin besar mutu betonnya, semakin besar nilai Faktor Kohesip $\left(\mathrm{K}_{\mathrm{p}}\right)$ saat keteguhan optimal (Toughness) mengalami peningkatan; untuk mutu dari $\mathrm{f}_{\mathrm{c}}^{\prime}-25 \mathrm{ke} \mathrm{f}_{\mathrm{c}}{ }^{\prime}-35$ sebesar $9,091 \%$, sedangkan dari $\mathrm{f}_{\mathrm{c}}-25$ ke $\mathrm{f}_{\mathrm{c}}{ }^{\prime}-55$ sebesar $71,428 \%$.

\section{b.Penelitian dari Rochman A.:}

"Analisis Ketegaran Retak Beton Fiber dengan Model Retak Dua-Parameter ". Hasil: Penambahan fiber dengan volume fraksi $0,7 \%$ dapat meningkatkan ketegaran retak beton yang ditunjukkan peningkatan $\mathrm{a}_{\mathrm{c}}$ sebesar $15,2 \%$, CTOD sebesar $52 \%$ dan $\mathrm{K}_{\mathrm{IC}}$ sebesar $25,4 \%$.

\section{c.Ta-Peng Chang, Mei-Miao Shieh,1996 :}

Ketegaran yang menyangkut nilai energi retak $\left(\mathrm{G}_{\mathrm{f}}\right)$ pada beton ringan tanpa tulangan/polos hanya sekitar $38 \mathrm{~N} / \mathrm{m}$.

\section{METODOLOGI}

Penelitian ini dilakukan di Laboratorium bahan bangunan/beton dan Laboratorium Struktur Jurusan Teknik Sipil, Politeknik Negeri - Malang. Dimana pelaksanaannya direncanakan dimulai pada bulan Agustus - September 2013 (selama dua bulan).

Bahan yang digunakan untuk Penelitian:

1. Semen Portland type I, dengan merek dagang "Semen Gresik". 
2. Agrerat halus yang digunakan adalah pasir alam berasal kali Brantas- Kota Malang.

3. Agrerat kasar batu pecah yang digunakan dari desa waleng pasuruan dengan sebutan Batu Kali Welang Ampuh (BKWA) CV ETIKA.

4. Air yang digunakan adalah air yang ada di laboraturium bahan bangunan dan beton Politeknik Negeri Malang.

\section{Proses Mix Design dan Benda Uji.}

Mix Design adalah menentukan campuran bahan beton atau perbandingan bahan beton yang dipakai sehingga dapat dicapai mutu beton yang direncanakan. Pada penelitian terapan ini perhitungan Mix Design menggunakan metode SK SNI T $15-1990-03$.

\section{Rancangan dan Perlakuan Percobaan.}

Rancangan percobaan tentang Ketegaran ini dipokuskan pada ketegaran pre peak dan ketegaran post peak, seperti ditunjukkan pada gambar 11:

Adapun rancangan percobaan sebagai berikut :

Tabel 1. Rancangan percobaan Penelitian :

\begin{tabular}{|c|c|c|c|c|}
\hline \multicolumn{5}{|c|}{ RANC. PENELITIAN: } \\
\hline \multirow{2}{*}{\multicolumn{2}{|c|}{ 1. $\begin{array}{l}\text { Agregat kasar } \\
\text { Batu Pecah } \\
\text { diameter } \\
\theta 20 \mathrm{~mm}\end{array}$}} & \multicolumn{3}{|c|}{ Faktor Air Semen = F.A.S } \\
\hline & & $\begin{array}{c}\text { F.A.S }= \\
0,35\end{array}$ & $\begin{array}{c}\text { F.A.S }= \\
\mathbf{0 , 4 0}\end{array}$ & $\begin{array}{c}\text { F.A.S }= \\
0,45\end{array}$ \\
\hline 2. & $\begin{array}{l}\text { Jumlah } \\
\text { Silinder } \theta 15 \text { - } 30\end{array}$ & $\begin{array}{c}10 \\
\text { buah }\end{array}$ & $\begin{array}{c}10 \\
\text { buah }\end{array}$ & $\begin{array}{c}10 \\
\text { buah }\end{array}$ \\
\hline
\end{tabular}

Benda uji berupa Silinder dengan ukuran seperti yang telah dirancang di atas direndam selama 26 hari untuk masingmasing benda uji.

\section{Diagram Alir Penelitian.}

Adapun kejelasan dalam rancangan penelitian dapat dilihat dalam gambar 10 . diagram alir dibawah ini : 


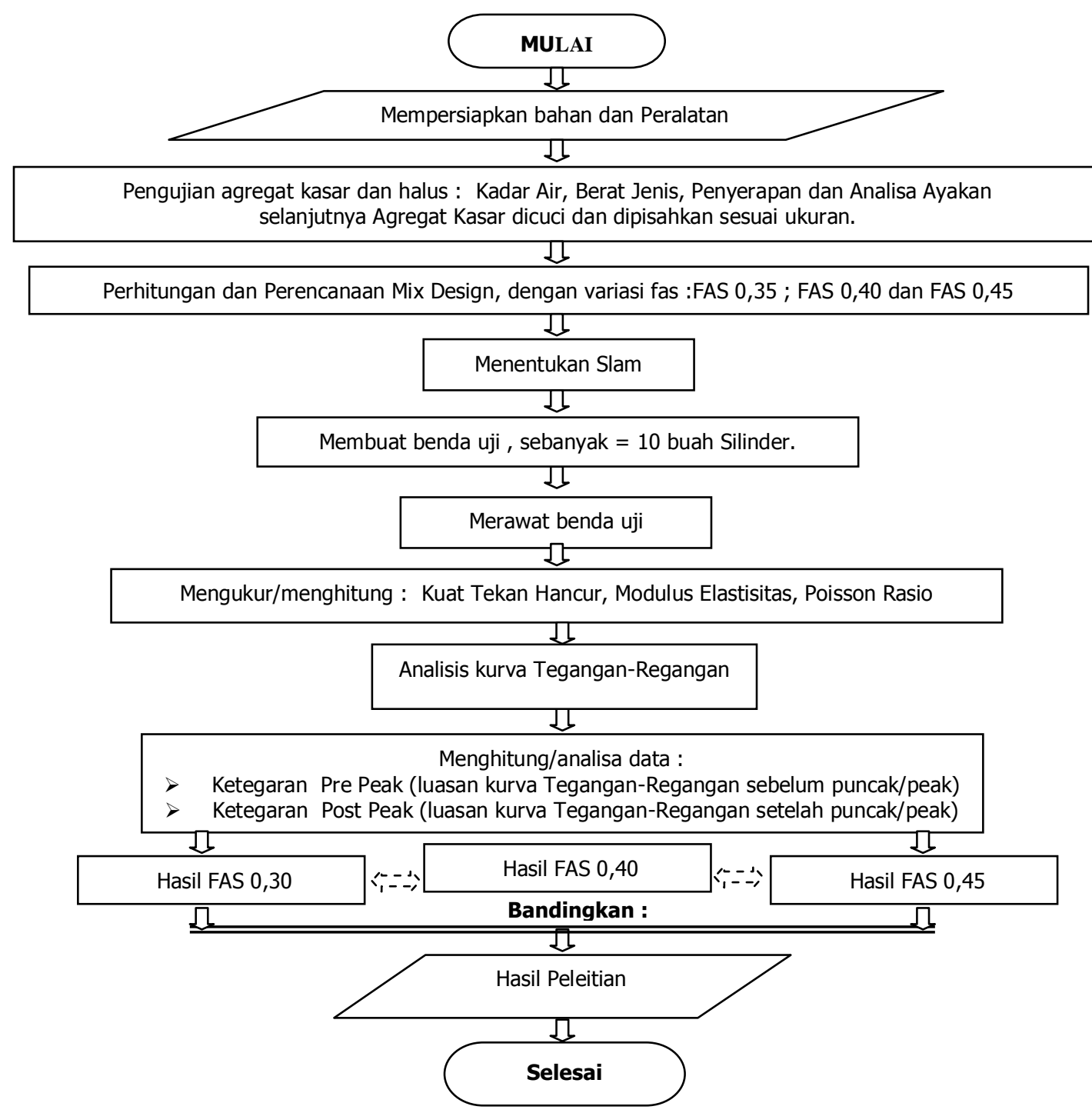

Gbr 10. Diagram Alir Pengujian

Formulasi Pengamatan Ketegaran

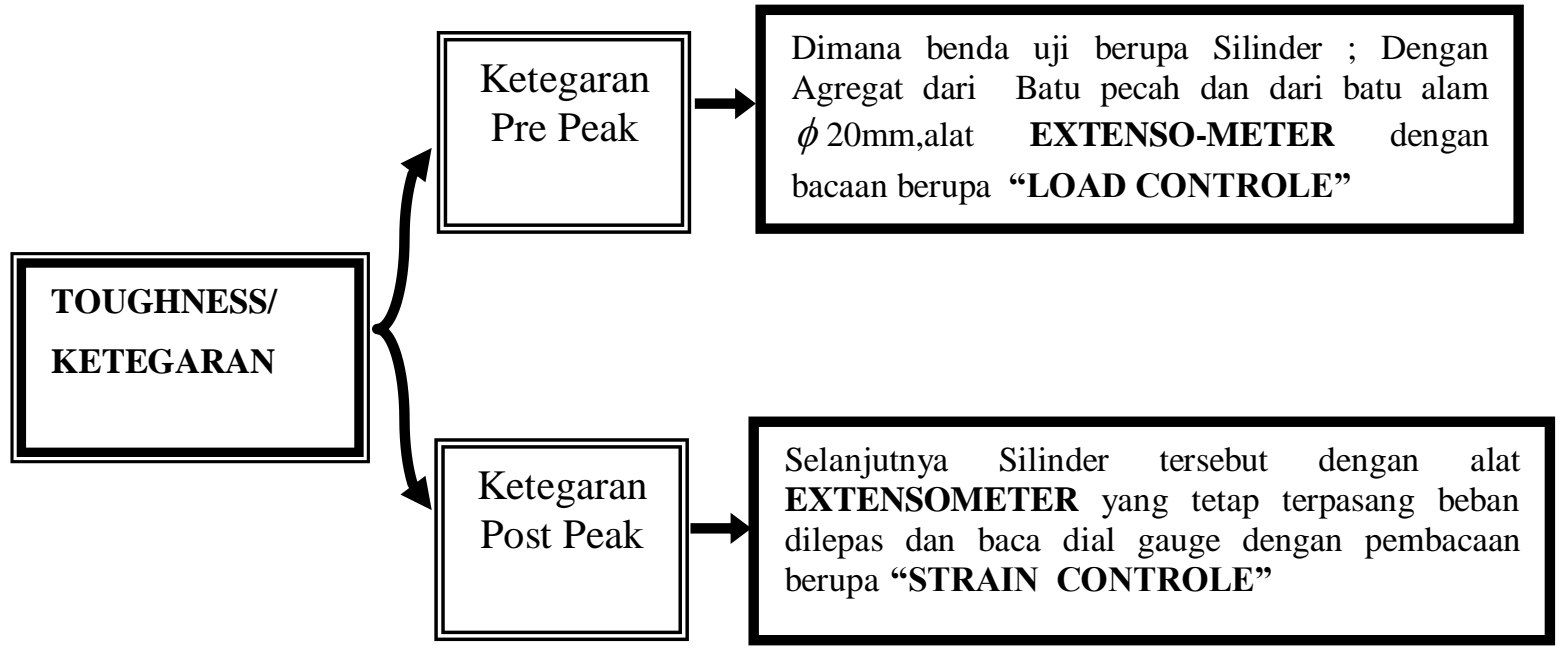

Gbr 11. Rancangan Pengamatan Ketegaran 


\section{Analisis Data Ketegaran}

Untuk mengetahui dan menghitung besar ketegaran pada tiap-tiap perlakuan digunakan formulasi sebagai berikut :

a. Menghitung luas permukaan dibawah kurva Beban-Penurunan $=\mathrm{W}$

b. Menghitung Besar Energi Retak /Work of Fracture $=\mathrm{G}_{\mathrm{f}}$.

c. Menghitung besar Faktor Intensitas Tegangan $($ Ketegaran $)=\mathrm{K}$.

\section{HASIL DAN PEMBAHASAN}

Pengujian karakteristik bahan yang digunakan pada penelitian ini dilakukan di Laboratorium Bahan Bangunan dan Beton Politeknik Negeri - Malang, pada tanggal 19-31 Agustus 2013. Diperoleh hasil sesuai dengan standart di Laboratorium sebagai berikut:

\section{Kadar air agregat;}

1. Agregat kasar; kadar air rata-rata untuk $\varnothing$ maksimum $20 \mathrm{~mm}=2.78 \%$

2. Agregat halus; Kadar air rerata $=$ $4,11 \%$

\section{Berat jenis dan Penyerapan}

1. Agregat kasar;

$\mathrm{Bj}$ ssd rata-rata $=2,58$

Penyerapan $=3,40 \%$

2. Agregat halus;

Bj ssd rata-rata $=2,35$

Penyerapan $=1,82 \%$

Analisa ayak agregat

1. Agregat kasar;

Modulus kehalusan $=8,26$

2. Agregat halus;

Modulus kehalusan $=4,04$

\section{Hasil perencanaan campuran (Mix design):}

\section{Agregat ø $20 \mathrm{~mm}$ : Mix design FAS 0.35}

Kebutuhan bahan tiap m3 campuran beton setelah dikoreksi;

1 Semen Portland $(\mathrm{PC}) \quad=585,71 \mathrm{~kg}$

2 Air $\quad=210,215 \mathrm{~kg}$

3 Agregat halus $\quad=711,809 \mathrm{~kg}$

4 Agregat kasar $\quad=880,266 \mathrm{~kg}$

Kebutuhan bahan dalam satu kali pengadukan, volume $=0,18 \mathrm{~m}^{3}$ :

Semen Portland $(\mathrm{PC})=0,18 \times 585,71=105,43 \mathrm{~kg}$
Air

Agregat halus

Agregat kasar

$=0,18 \times 210,215=37,84 \mathrm{~kg}$

$=0,18 \times 711,809=128,13 \mathrm{~kg}$

$=0,18 \times 880,266=158,45 \mathrm{~kg}$

\section{Agregat $\emptyset 20 \mathrm{~mm}$ : Mix design FAS}

0.40

Kebutuhan bahan tiap m3 campuran beton setelah dikoreksi;

$\begin{array}{lll}1 & \text { Semen Portland }(\mathrm{PC}) & =512,50 \mathrm{~kg} \\ 2 & \text { Air } & =210,454 \mathrm{~kg} \\ 3 & \text { Agregat halus } & =744,433 \mathrm{~kg} \\ 4 & \text { Agregat kasar } & =920,613 \mathrm{~kg}\end{array}$

Kebutuhan bahan dalam satu kali pengadukan, volume $=0,18 \mathrm{~m}^{3}$ :

Semen Portland $(\mathrm{PC})=0,18 \times 512,50=92,25 \mathrm{~kg}$

Air $\quad=0,18 \times 210,454=37,88 \mathrm{~kg}$

Agregat halus $\quad=0,18 \times 744,433=133,99 \mathrm{~kg}$

Agregat kasar $\quad=0,18 \times 920,613=165,71 \mathrm{~kg}$

\section{Agregat $\emptyset 20 \mathrm{~mm}$ : Mix design FAS \\ 0.45}

Kebutuhan bahan tiap m3 campuran beton setelah dikoreksi;

$\begin{array}{lll}1 & \text { Semen Portland ( PC ) } & =418,37 \mathrm{~kg} \\ 2 & \text { Air } & =189,08 \mathrm{~kg} \\ 3 & \text { Agregat halus } & =972,49 \mathrm{~kg} \\ 4 & \text { Agregat kasar } & =808,06 \mathrm{~kg}\end{array}$

Kebutuhan bahan dalam satu kali pengadukan, volume $=0,18 \mathrm{~m}^{3}$ :

Semen Portland $(\mathrm{PC})=0,18 \times 418,37=75,31 \mathrm{~kg}$

Air $\quad=0,18 \times 189,08=34,03 \mathrm{~kg}$

Agregat halus $\quad=0,18 \times 808,06=145,45 \mathrm{~kg}$

Agregat kasar $\quad=0,18 \times 972,49=175,05 \mathrm{~kg}$

Analisa Hasil Pengujian Faktor Air Semen (FAS)

\section{Beton FAS 0.35}

Proporsi campura beton :

- Semen Tiga Roda Type I : $105.43 \mathrm{~kg}$

- Air $\quad: 37.84 \mathrm{~kg}$

- Pasir $\quad: 128.13 \mathrm{~kg}$

- Batu pecah $\quad: 158.45 \mathrm{~kg}$

Nilai slump Beton : $7.5 \mathrm{~cm}$

Hasil Kuat Tekan Beton; FAS 0,35

Dari hasil pengujian didapatkan nilai kuat tekan individu rata-rata beton pada umur 3 hari sebesar 26.31 Mpa dan pada umur 7 hari sebesar 23.36 Mpa.

\section{Beton FAS 0.40}

Proporsi campura beton :

- Semen Tiga Roda Type I : $92.25 \quad \mathrm{~kg}$

- Air : $37.881 \mathrm{~kg}$

- Pasir : $133.997 \mathrm{~kg}$

- Batu pecah : $165.710 \mathrm{~kg}$ 
Nilai slump Beton : $8.2 \mathrm{~cm}$

Hasil Kuat Tekan Beton; FAS 0,35

Dari hasil pengujian didapatkan nilai kuat tekan individu rata-rata beton pada umur 3 hari sebesar 22.16 Mpa dan pada umur 7 hari sebesar 26.68 Mpa.

\section{Beton FAS 0.45}

Proporsi campura beton :

- Semen Tiga Roda Type I : $79.5855 \mathrm{~kg}$

- Air

- Pasir $: 31.382 \mathrm{~kg}$

- Batu pecah $: 118.329 \mathrm{~kg}$ $: 145.404 \mathrm{~kg}$

Nilai slump Beton : $9.4 \mathrm{~cm}$

Hasil Kuat Tekan Beton; FAS 0,35

Dari hasil pengujian didapatkan nilai kuat tekan individu rata-rata beton pada umur 3 hari sebesar $22.73 \mathrm{Mpa}$ dan pada umur 7 hari sebesar $20.98 \mathrm{Mpa}$.

\section{Pembahasan Besar Kuat Tekan Beton}

Hasil pengujian di atas dapat diringkas dalam tabel sebagai berikut:

Nilai Kuat Tekan Beton Usia 7 hari Untuk Beberapa Variasi FAS dan Diameter Maksimum Agregat (Mpa)

\begin{tabular}{|r|c|c|c|}
\hline fas & $\mathbf{0 . 3 5}$ & $\mathbf{0 . 4 0}$ & $\mathbf{0 . 4 5}$ \\
\hline $20 \mathrm{~mm}$ & 26.68 & 23.36 & 20.98 \\
\hline
\end{tabular}

1. Pemilihan faktor air semen dalam perencanaan campuran sangat menentukan pembentukan rongga dalam beton setelah mengeras. Terbentuknya rongga dalam beton akan mengakibatkan kekuatan beton berkurang. Hal ini dapat kita lihat dari hasil pengujian di atas, dimana nilai terkecil faktor air semen yang dipilih, yaitu 0.35 ternyata nilai kuat tekan rata-rata yang paling tinggi, dibandingkan nilai faktor air semen yang lebih tinggi.

Berdasarkan uraian di atas dapat disimpulkan bahwa "Pada bahan-bahan beton dan kondisi pengujian tertentu, jumlah air dalam campuran (faktor air semen) menentukan kekuatan beton, selama campuran cukup plastis dan dapat dikerjakan". Hal ini berarti bahwa beton yang dipadatkan sempurna dengan agregat yang baik dan pada kadar semen tertentu, maka kekuatannya tergantung pada faktor air semen.

2. Pencapaian kemampatan beton dilakukan pula dengan perlakuan pemadatan saat beton masih berada dalam kondisi plastis

3. Secara kuantitatif ketegaran yang merupakan terminology lain dari datilitas, dapat didefinisikan sebagai kemampuan material untuk mendisipasi energy, yaitu selisih energy yang diserap dengan energy yang dilepaskan. Semakin daktail materialnya, semakin besar pula kemampuannya untuk mendidipasi energi. Dalam pengujian yang telah dilakukan tampak bahwa energy yang diberikan oleh mesin uji tekan dalam bentuk gaya tekan didisipasi oleh benda uji ke setiap elemen dari matriks penyusunnya, dengan asumsi bahwa setiap campuran memiliki nilai regangan yang sama. Untuk itu, semakin besar nilai kekuatan tekan yang dicapai akan menunjukkan semakin daktail beton tersebut.

\section{Besar Poisson Rasio $=v$ :}

Dengan menggunakan rumus: $v=\frac{\varepsilon_{t}}{\varepsilon_{l}}$

sampai pada kondisi Elastis yang direkomendasikan oleh SNI sebesar $=45 \%$ dari tegangan puncak (peak).

Dimana : $v=$ nilai poisson ratio; $\varepsilon_{t}=$ regangan transversal dan $\varepsilon_{l}=$ regangan longitudinal

Diperoleh besar poisson benda uji sesuai dengan mix design sebagai berikut:

\begin{tabular}{|c|c|c|c|}
\hline Bd.Uji & Fas 0,35 & Fas 0,40 & Fas 0,45 \\
\hline 1 & 0,331 & 0,269 & 0,209 \\
\hline 2 & 0,28 & 0,235 & 0,245 \\
\hline 3 & 0,295 & 0,296 & 0,266 \\
\hline 4 & 0,355 & 0,255 & 0,225 \\
\hline 5 & 0,45 & 0,36 & 0,274 \\
\hline 6 & 0,365 & 0,334 & 0,334 \\
\hline 7 & 0,368 & 0,255 & 0,316 \\
\hline 8 & 0,288 & 0,375 & 0,305 \\
\hline 9 & 0,291 & 0,242 & 0,138 \\
\hline 10 & 0,293 & 0,222 & 0,220 \\
\hline Rata2 & $\mathbf{0 , 3 3 2}$ & $\mathbf{0 , 2 8 1}$ & $\mathbf{0 , 2 6 1}$ \\
\hline
\end{tabular}


Menghitung Mod. Elastisitas $\left(\mathbf{E}_{\mathbf{C}}\right)$ dan Luas Kurva Beban-Regangan (W): Pers. Kurva untuk $E_{C}$ dan W

Data-data yang diperoleh dari pengujian, diolah untuk mencari nilai actual yang sebenarnya pada benda uji sebagaimana sudah dijelaskan pada langkah sebelumnya. Diplot hubungan antara tegangan dan regangan longitudinal $\left(\Delta_{l}\right)$ yang diolah dengan "Microsoft Excel". Selanjutnya di add-trendline agar didapat persamaan kurvanya. Untuk persamanaan kurva menghitung Modulus Elastisitas hanya hubungan antara tegangan dan regangan pada pembacaan beban naik, sedangkan untuk persamaan kurva menghitung luas kurva adalah hubungan antara beban (Py) penurunan actual $\left(\Delta_{l}\right)$ pada pembacaan beban naik dan beban turun. Persamaan kurva untuk Modulus Elastisitas polynominal pangkat 2 dan untuk luasan kurva ada yang polynominal pangkat 2, atau pangkat 3 , dan/atau pangkat 4 sesuai dengan $\mathrm{R}^{2} \leq 1$. Berikut ini salah satu contoh persamaan kurva untuk Modulus Elastisitas dan luasan kurva.

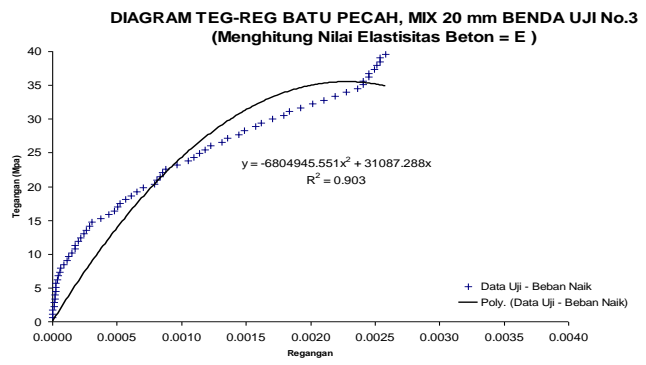

Persamaan kurva untuk "Modulus Elastisitas (Ec)" setiap benda uji dicari dengan langkah seperti di atas, akan diperoleh persamaan sebagai berikut :

\begin{tabular}{|c|c|c|c|}
\hline No & Bd.Uji & Pers.Kurva - M. Elastisitas $(E c)$ & $\mathrm{R}^{2}$ \\
\hline 1 & B-1El & $\mathrm{y}=-4957534.3 \cdot \mathrm{x} 2+26371.7 \cdot \mathrm{x}$ & 0,99 \\
\hline 2 & B-2El & $\mathrm{y}=-6226195.0 \cdot \mathrm{x} 2+31768.0 \cdot \mathrm{x}$ & 0,996 \\
\hline 3 & B-3El & $\mathrm{y}=-6804945.5 \cdot \mathrm{x} 2+31087.2 \cdot \mathrm{x}$ & 0,903 \\
\hline 4 & B-4El & $\mathrm{y}=-6863529.8 \cdot \mathrm{x} 2+33166.6 \cdot \mathrm{x}$ & 0,992 \\
\hline 5 & B-5El & $\mathrm{y}=-5319435.5 \cdot \mathrm{x} 2+30268.4 \cdot \mathrm{x}$ & 0,993 \\
\hline 6 & B-6El & $\mathrm{y}=-5753421.3 \cdot \mathrm{x} 2+67371.7 \cdot \mathrm{x}$ & 0,994 \\
\hline 7 & B-7El & $\mathrm{y}=-6456795.0 \cdot \mathrm{x} 2+32348.0 \cdot \mathrm{x}$ & 0,989 \\
\hline 8 & B-8El & $\mathrm{y}=-6745545.5 \cdot \mathrm{x} 2+39987.2 \cdot \mathrm{x}$ & 0,935 \\
\hline 9 & B-9El & $\mathrm{y}=-4773529.8 \cdot \mathrm{x} 2+76566.6 \cdot \mathrm{x}$ & 0,972 \\
\hline 10 & B-10E & $\mathrm{y}=-4489435.5 \cdot \mathrm{x} 2+67768.4 \cdot \mathrm{x}$ & 0,983 \\
\hline
\end{tabular}

DIAGRAM BEBAN (P) - PENURUNAN（）, B.Pch MIX 20mm - B.UJI No.3 (Menghitung Luas Kurva $=\mathrm{W}(\mathrm{N} . \mathrm{mm})$

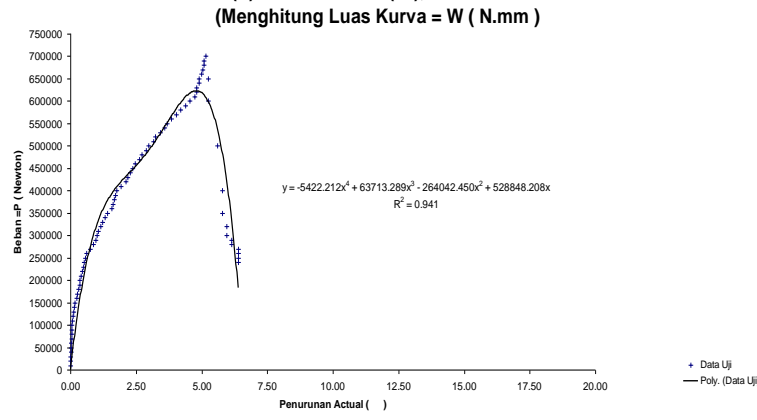

Persamaan kurva untuk "menghitung luasan kurva (W)" setiap benda uji dicari dengan langkah seperti di atas, akan diperoleh persamaan sebagai berikut :

\begin{tabular}{|c|c|c|c|}
\hline $\mathrm{N}$ & $\begin{array}{c}\text { Bd. } \\
\text { Uji }\end{array}$ & Pers.Kurva - Hitung Luas $(\mathrm{W})$ & $\mathrm{R}^{2}$ \\
\hline 1 & B-1Lu & $\mathrm{y}=-4164268.2 \cdot \mathrm{x} 2+24590.4 \cdot \mathrm{x}$ & 0,96 \\
\hline 2 & $\mathrm{~B}-2 \mathrm{Lu}$ & $\mathrm{y}=-8654779.6 \cdot \mathrm{x} 2+34693.0 \cdot \mathrm{x}$ & 0,95 \\
\hline 3 & $\mathrm{~B}-3 \mathrm{Lu}$ & $\mathrm{y}=-59766984.5 \cdot \mathrm{x} 2+59853.3 \cdot \mathrm{x}$ & 0,94 \\
\hline 4 & $\mathrm{~B}-4 \mathrm{Lu}$ & $\mathrm{y}=-9855715.4 \cdot \mathrm{x} 2+37344.3 \cdot \mathrm{x}$ & 0,96 \\
\hline 5 & $\mathrm{~B}-5 \mathrm{Lu}$ & $\mathrm{y}=-6373808.2 \cdot \mathrm{x} 2+31753.1 \cdot \mathrm{x}$ & 0,99 \\
\hline 6 & $\mathrm{~B}-6 \mathrm{Lu}$ & $\mathrm{y}=-3784268.9 \cdot \mathrm{x} 2+54290.1 \cdot \mathrm{x}$ & 0,93 \\
\hline 7 & $\mathrm{~B}-7 \mathrm{Lu}$ & $\mathrm{y}=-5664779.2 \cdot \mathrm{x} 2+66793.6 \cdot \mathrm{x}$ & 0,99 \\
\hline 8 & $\mathrm{~B}-8 \mathrm{Lu}$ & $\mathrm{y}=-59766984.5 \cdot \mathrm{x} 2+59853.3 \cdot \mathrm{x}$ & 0,98 \\
\hline 9 & $\mathrm{~B}-9 \mathrm{Lu}$ & $\mathrm{y}=-7655715.3 \cdot \mathrm{x} 2+66744.21 \cdot \mathrm{x}$ & 0,97 \\
\hline 10 & $\mathrm{~B}-10 \mathrm{~L}$ & $\mathrm{y}=-7383812.7 \cdot \mathrm{x} 2+75353.9 \cdot \mathrm{x}$ & 0,92 \\
\hline
\end{tabular}

Besar Modulus Elastisitas Beton $=\mathbf{E}_{\mathbf{C}}$ :

Diperoleh besar Modulus Elastisitas benda uji sesuai mix design dari data-data pengujian kuat tekan dengan memakai persamaan kurva yang ada pada langkah 4.7.1 di atas. Menggunakan Program Matematika "DERIVE fo Windows VERSION 4" dengan langkah sebagai berikut :

1. Buka program derive, lalu klikauthor expression (simbol/tampilan pensil).

2. Copy persamaan kurva yang sudah di trendline dari data asli pengujian dan di paste pada kotak yang tersedia, lalu edit sesuai persamaan yang sebenarnya teristimewa tentang pangkat polynominalnya $\rightarrow$ OK

3. Klik calculate derivative/turunan $($ simbol $\partial$ ), variable $\mathrm{x}$ orde- $1 \rightarrow \mathrm{OK}$

4. Klik simplify ( solve algebraically $\rightarrow$ OK

5. Klik approximate ( simbol $\approx)$, diperoleh nilai $\mathrm{x}$ atau $=\boldsymbol{\varepsilon}$

6. Klik edit expression $\rightarrow$ OK 
7. Selanjutnya edit expression persamaan awal lalu klik simplify substitute for variables substitution \#6 (langkah no 6) $\rightarrow$ OK

8. Klik solve algebraically $\rightarrow$ OK

9. Klik simbol $\approx$ diperoleh y maksimum atau $=\sigma-$ maksimum

10. Klik edit expression $\rightarrow$ OK

11. Selanjutnya edit expression persamaan awal ganti nilai $\mathrm{y}=40 \% \mathrm{x}$ langkah no 9 atau nilai ini $=\sigma_{1}$

12. Klik solve algebraically $\rightarrow \mathrm{OK}$

13. Klik simbol $\approx$ diperoleh nilai $\mathrm{x}_{1}$ dan $\mathrm{x}_{2}$, pilih nilai yang paling memenuhi $=$ $\varepsilon_{1}$

14. Selanjutnya edit expressioan persamaan awal ganti nilai $\mathrm{x}=$ $0,00005 \rightarrow$ OK

15. Klik solve algebraically $\rightarrow$ OK

16. Klik simbol $\approx$ diperoleh $\sigma_{2}$

17. Klik edit expression $\rightarrow \mathrm{OK}$

18. Terakhir dihitung nilai Modulus

Elastisitas beton dengan rumus

modulus chord, yaitu : $E_{c}=\frac{\sigma_{1}-\sigma_{2}}{\varepsilon_{l}-0,00005}$

19. Diperoleh nilai Modulus Elastisitas seperti tabel berikut ini :

\begin{tabular}{|c|c|c|c|}
\hline Bd.Uji & Fas 0,35 & Fas 0,40 & Fas 0,45 \\
\hline 1 & 24,392 & 24,296 & 22,192 \\
\hline 2 & 23,861 & 24,035 & 23,060 \\
\hline 3 & 24,045 & 23,501 & 22,145 \\
\hline 4 & 25,763 & 23,466 & 22,163 \\
\hline 5 & 23,761 & 21,953 & 23,261 \\
\hline 6 & 23,875 & 22,675 & 22,175 \\
\hline 7 & 24,756 & 23,758 & 23,056 \\
\hline 8 & 24,821 & 22,987 & 22,221 \\
\hline 9 & 23,789 & 23,753 & 23,129 \\
\hline 10 & 24,886 & 22,876 & 21,256 \\
\hline Rata2 & $\mathbf{2 4 , 3 9 5}$ & $\mathbf{2 3 , 3 5 1}$ & $\mathbf{2 2 , 4 6 6}$ \\
\hline
\end{tabular}

Besar Luas Kurva Beban-Reg.= $\mathrm{W}=$ (N.mm)

Menggunakan Program Matematika : "DERIVE for Windows VERSION 4" dengan langkah sebagai berikut :

1. Buka program derive, lalu klik author expression (simbol/tampilan pensil).

2. Copy persamaan kurva (BebanPenurunan) yang sudah di trendline dari data asli pengujian dan di paste pada kotak yang tersedia, lalu edit sesuai persamaan yang sebenarnya tentang pangkat polynominal $\rightarrow$ OK
3. Klik calculate integral (simbol $\int$ ), variable $\mathrm{x}$, integral definite isi; lower limit $=0$ dan upper limit $=6,9650$ (misalnya $=$ batas atas $) \rightarrow$ OK

4. Klik simplify ( $\operatorname{simbol}=$ ), selanjutnya solve algebraically $\rightarrow$ OK

5. Klik approximate (simbol $\approx$ ), diperoleh nilai $\mathrm{x}$ atau $=\varepsilon$

6. Klik edit expression $\rightarrow \mathrm{OK}$

7. Diperoleh luas yang dicari seperti tabel berikut ini :

\begin{tabular}{|c|c|c|c|}
\hline Bd.Uji & Fas 0,35 & Fas 0,40 & Fas 0,45 \\
\hline 1 & 1,421 & 1,225 & 1,122 \\
\hline 2 & 1,331 & 1,219 & 1,351 \\
\hline 3 & 1,323 & 1,272 & 1,351 \\
\hline 4 & 1,411 & 1,281 & 1,223 \\
\hline 5 & 1,526 & 1,311 & 1,252 \\
\hline 6 & 1,427 & 1,321 & 1,271 \\
\hline 7 & 1,339 & 1,291 & 1,198 \\
\hline 8 & 1,415 & 1,219 & 1,205 \\
\hline 9 & 1,325 & 1,201 & 1,199 \\
\hline 10 & 1,221 & 1,279 & 1,201 \\
\hline Rata2 & $\mathbf{1 , 3 7 4}$ & $\mathbf{1 , 2 6 2}$ & $\mathbf{1 , 2 1 7}$ \\
\hline
\end{tabular}

Menghitung Besar Energi Retak/Work of Fracture $\left(\mathbf{G}_{\mathbf{f}}\right)$

Untuk menghitung besar energy retak/work of fracture dihitung dulu besar dari luas retak yang terjadi, lalu digunakan rumus :

$$
G_{f}=\frac{\text { Luas Kurva }}{\text { Luas Retak }}=\frac{W}{A}
$$

Luas retak yang terjadi berbentuk "ellips" seperti ditunjukkan gambar di atas, dimana :

Luas ellips $=\mathrm{A}=\pi \cdot a \cdot b$

$$
\begin{array}{r}
=\pi \cdot(0,075) \cdot(0,1677)=0,03951 \mathrm{~m}^{2} . \\
G_{f}=\frac{\text { Luas Kurva }}{\text { Luas } \operatorname{Re} t a k}=\frac{W}{A} ; \text { sehingga }=\frac{N \cdot m}{m^{2}}=\frac{N}{m}
\end{array}
$$

Sehingga Besar Energi Retak/Work of Fracture $\left(\mathrm{G}_{\mathrm{f}}\right)$, diperoleh seperti tabel berikut :

\begin{tabular}{|c|c|c|c|}
\hline Bd.Uji & Fas 0,35 & Fas 0,40 & Fas 0,45 \\
\hline 1 & 35,940 & 33,250 & 31,400 \\
\hline 2 & 33,680 & 32,350 & 33,680 \\
\hline 3 & 33,490 & 33,975 & 29,010 \\
\hline 4 & 35,720 & 35,555 & 32,190 \\
\hline 5 & 38,610 & 33,421 & 30,960 \\
\hline 6 & 35,500 & 35,230 & 31,700 \\
\hline 7 & 36,250 & 34,475 & 312,955 \\
\hline 8 & 34,760 & 35,400 & 31,750 \\
\hline 9 & 35,750 & 35,925 & 31,250 \\
\hline 10 & 36,115 & 33,250 & 30,555 \\
\hline Rata2 & $\mathbf{3 5 , 5 8 2}$ & $\mathbf{3 4 , 2 8 3}$ & $\mathbf{3 1 , 4 4 5}$ \\
\hline
\end{tabular}




\section{Menghitung Faktor Intensitas Tegangan} (K)

Setelah nilai Modulus Elastisitas beton ( E ) dan besar energi retak/work of fracture $\left(G_{f}\right)$ diperoleh, langkah selanjutnya menghitung besar "factor intensitas tegangan $(\mathrm{K})$ " dengan rumus :

$$
K=\sqrt{E \cdot G_{f}}(\text { Shah dkk, 1995) }
$$

Dengan bantuan "Microsoft excel", diperoleh hasil seperti tabel berikut ini:

\begin{tabular}{|c|c|c|c|}
\hline Bd.Uji & Fas 0,35 & Fas 0,40 & Fas 0,45 \\
\hline 1 & 0,888 & 0,827 & 0,822 \\
\hline 2 & 0,889 & 0,853 & 0,930 \\
\hline 3 & 0,887 & 0,895 & 0,835 \\
\hline 4 & 0,927 & 0,891 & 0,860 \\
\hline 5 & 0,969 & 0,825 & 0,842 \\
\hline 6 & 0,875 & 0,876 & 0,865 \\
\hline 7 & 0,928 & 0,869 & 0,665 \\
\hline 8 & 0,995 & 0,891 & 0,752 \\
\hline 9 & 0,875 & 0,858 & 0,825 \\
\hline 10 & 0,895 & 0,879 & 0,880 \\
\hline Rata2 & $\mathbf{0 , 9 0 9}$ & $\mathbf{0 , 8 6 6}$ & $\mathbf{0 , 8 2 8}$ \\
\hline
\end{tabular}

\section{SIMPULAN}

1. Dari komposisi campuran berdasarkan FAS, tampak bahwa campuran yang menggunakan FAS terendah, yaitu 0.35 akan memberikan nilai kuat tekan dan modulus elestisitas yang lebih tinggi menjadi 23,36 $\mathrm{MPa}$ pada FAS 0.40 $(11,34 \%)$ dan meningkat menjadi 26,68 MPa pada FAS $0.35(27,17 \%)$.

2. Rendahnya faktor air semen juga merupakan jaminan terkendalinya deformasi susut-rangkak yang seringkali menimbulkan retak mikro yang akan mengurangi kekuatan beton. Hal ini terlihat dari nilai Luas Kurva BebanPenurunan (W) untuk FAS $0.45=1,217$ N.mm , meningkat menjadi 1,262 N.mm pada FAS $0.40(3,69 \%)$ dan meningkat menjadi 1,374 N.mm pada FAS 0.35 $(12,90 \%)$

3. Dari komplosisi campuran berdasarkan FAS, tampak bahwa campuran yang menggunakan FAS terendah, yaitu 0.35 akan memberikan nilai Besar Energi Retak/Work of Fracture $\left(G_{f}\right)$ yang lebih tinggi. Hal ini terlihat dari nilai Besar Energi Retak/Work of Fracture $\left(\mathrm{G}_{\mathrm{f}}\right)$ untuk FAS $0.45=31,445 \mathrm{~N} / \mathrm{m}$, meningkat menjadi $34,582 \mathrm{~N} / \mathrm{m}$ pada FAS $0.40 \quad(9,025 \%)$ dan meningkat menjadi $35,582 \mathrm{~N} / \mathrm{m}$ pada FAS 0.35 $(13,156 \%)$

4. Dalam pengujian yang telah dilakukan tampak bahwa energi yang diberikan oleh mesin uji tekan dalam bentuk gaya tekan didisipasi oleh benda uji ke setiap elemen dari matriks penyusunnya, dengan asumsi bahwa setiap campuran memiliki regangan yang sama. Untuk itu, semakin besar nilai kekuatan yang dicapai akan menunjukkan semakin daktail beton tersebut. Hal ini terlihat dai nilai Intensitas Tegangan/Stress Intensity Factor (K) untuk FAS $0.45=0,8267$ $\mathrm{N} / \mathrm{m}$, meningkat menjadi $0,8664 \mathrm{~N} / \mathrm{m}$ pada FAS $0.40(4,80 \%)$ dan meningkat menjadi $0,9088 \mathrm{~N} / \mathrm{m}$ pada FAS 0.35 $(9,93 \%)$.

\section{DAFTAR PUSTAKA}

American Concrete Institute. 1996.ACI Manual of Concrete Practice (Materials and General Propeties of Concrete)- Part.1, Editorial Production : Victoria A.Lunick.

ASTM C 1018 -94b.1996. Annual Book of ASTM Standards , Vol.04.02, "Concrete and Aggregates" - Printed in Easton, MD, USA.

Basyar Bustan,Abdul Fattah,Abdul Nabi.2003. Kuat Tekan Beton Menggunakan Agregat Kasar Bergradasi/Berukuran Seragam, Jurnal Penelitian Teknik Sipil(INTENSIP), Tahun 2,Nomor 2, Oktober 2003, Politeknik Negeri Ujung Pandang-Makassar.

Bushby, A.J, Davies, C.K.L.1992. Structure and Fracture Behavior of GlassFiber-reinforced Mortars Containing Mica Flakes Cement, Omega Scientific, England. 
Brook, K.M. \& Murdock, L.J. 1979. Bahan dan Praktek Beton edisi ke - 4, Erlangga, Bandung.

Chen W.F \& Han D.J. 1988. Plasticity for Structural Engineers, SpingerVerlag, New York.

Chu-Kia Wang , Charles G.Salmon \& Binsar Harianja. 1994.Disain Beton Bertulang, Erlangga, Jakarta.

David Broek. 1986. Elementary Engineering Fracture Mechanics, Martinus Nijhoff Publishers, Netherlands.

David Roylance. 1996. Mechanics of Materials,John Wiley \& Sons,Inc, Canada.

Gideon Kusuma. 1993. Pedoman Pengerjaan Beton, Erlangga, Jakarta.

Lawrence H.Van Vlack. 2001. Elemenelemen Ilmu dan Rekayasa Material edisi Keenam, Erlangga.

Mindes S. and Francis Young F. 1981. Concrete , Prentice-Hall,Inc, Englewood Cliffs, New Jersey.

Mulyono, Tri. 2004. Teknologi Beton. Yogyakarta: ANDI.

Paulus Nugraha. 1993. Teknologi Beton dengan Antisipasi Tehadap Pedoman Beton 1989, Universitas Kristen Petra, Surabaya.
Rochman A. 2001. Analisis Ketegaran Retak Beton Fiber dengan Model Retak Dua-Parameter, Media Komunikasi Teknik Sipil, Vol.9,No.3,Edisi XXI, Oktober 2001, Univ.Diponegoro-Semarang.

Reda Taha M.M.\& Shrive N.G. 2001. Fracture of Civil Engineering Materials ENCI 617, Fracture of Concrete- Lecture Notes.

SK. SNI. T $-15-1990-03$. 1990. Tata Cara Pembuatan Rencana Campuran Beton Normal, Departeman Pekerjaan Umum, Bandung.

Sunardi. 2003. Menentukan Nilai Keteguhan Beton Normal dan Beton Mutu Tinggi pada Permukaan dalam Akibat Penurunan Faktor Kohesif, Media Komunikasi Teknik Sipil, Vol.11,No.3, Edisi XXVII , Oktober 2003, Univ.DiponegoroSemarang.

Ta-Peng Chang, Mei-Miao Shieh. 1996. Fracture Properties of Lightweight Concrete, Cement and Concrete Research, Vol.26,No.2,pp 181-188.

Tata Surdia dan Shinroku Saito. 2000. Pengetahuan Bahan Teknik, Pradnya Paramita, Jakarta.

Tri Mulyono. 2003. Teknologi Beton, ANDI, Yogyakarta.

Wuryati S. dan Candra R. 2001. Teknologi Beton, Kanisius, Yogyakarta. 